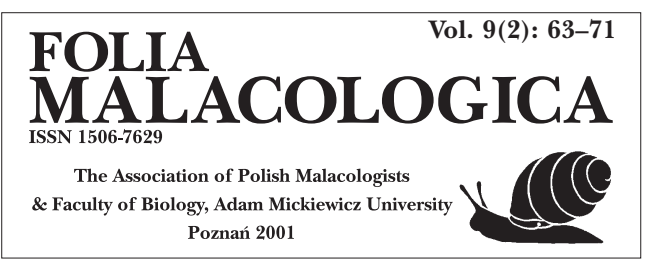

\title{
MORPHOLOGICAL VARIATION IN TERRESTRIAL SLUG DEROCERAS TURCICUM (SIMROTH, 1894) AND A NORTHERN EXTENSION OF ITS RANGE IN CENTRAL EUROPE
}

\author{
HEIKE REISE ${ }^{1}$, JOHN M. C. HUTCHINSON ${ }^{2}$ \\ ${ }^{1}$ Staatliches Museum für Naturkunde Görlitz, PF 300 154, D-02806 Görlitz, Germany \\ (e-mail: smng.reise@t-online.de) \\ ${ }^{2}$ Max Planck Institute for Human Development, Lentzeallee 94, D-14195 Berlin, Germany \\ (e-mail: hutch@mpib-berlin.mpg.de)
}

\begin{abstract}
We report seven new localities of the terrestrial slug Deroceras turcicum (Simroth), including the first occurrences in the Czech Republic and Slovakia. These demonstrate that the distribution of $D$. turcicum extends much further north than known previously and it might even be rather common there. We discuss possible reasons for its belated discovery. D. turcicum might have often been confused not only with the common D. reticulatum (O.F. Müll.) but also with the syntopical D. rodnae Grossu et Lupu and D. praecox Wiktor. We describe its variability in size, coloration, genital morphology, and caecum length, and consider characters for its reliable discrimination from other species. Two colour morphs (white and violet) are described for the first time. Intriguingly, the coloration of $D$. turcicum often matches that of congeners found at the same site, which suggests that colour has some selective value. Since external appearance often gives no reason to suspect that two species co-occur at a site, dissection of several specimens is advisable.
\end{abstract}

\section{INTRODUCTION}

Deroceras turcicum (Simroth, 1894) is a usually cream-coloured slug, externally indistinguishable from many other species in the genus, including the very common $D$. reticulatum (O.F. Müller, 1774). The external similarity is all the more troublesome as $D$. turcicum and D. reticulatum are also very similar and variable in their genital morphology. D. reticulatum is widespread in Europe, and has been introduced to many other areas of the world (BARKER 1999); it is nearly exclusively limited to habitats that have been to some extent disturbed (WIKTOR 2000). D. turcicum seems mainly to live in forests, but it can also be found in synanthropic habitats (WIKTOR 2000).

So far, D. turcicum is known from the Balkan Peninsula (Bulgaria, Romania, all countries of the area of former Yugoslavia, Greece, Albania), Turkey, Italy, Hungary and Austria (LUPU 1972, REISCHÜTZ 1986, DHORA \& WELTER-SCHULTES 1996, WIKTOR 2000 and pers. comm.). REISCHÜTZ (1986) mentioned that D. turcicum reaches the most north-western margin of its area in Austria. However, WIKTOR (1996) suggested that the species might be more widespread but had not been recognised owing to its similarity with $D$. reticulatum and to the high variability of both species.

Here we report a number of new localities for $D$. turcicum which throw a fresh light on its distribution. We discuss whether and why it might have been overlooked until now, make some novel observations on its external appearance, and examine which anatomical characters are distinctive.

Two further species will be considered in this context: D. praecox Wiktor, 1966, and D. rodnae Grossu et Lupu, 1965, are species of deciduous and mixed forests in mountains and their foothills. They are closely related to one another and distinguished from $D$. 
turcicum and D. reticulatum by a flat stimulator and a rudimentary caecum. D. rodnae occurs from the eastern Carpathians to SE France and in Spain (WIKTOR 2000). The range of $D$. praecox is much smaller, in the

\section{METHODS}

Most slugs were found during a collecting trip in spring 1999. However, a few localities were visited at a different time or more than once. Success was very poor during the daytime when it was dry, so most of our collecting was early in the morning. Slugs were killed either in about $50 \%$ ethanol, or by freezing (in an ultrafreezer at $-80^{\circ} \mathrm{C}$ or in a Dewar flask containing liquid nitrogen), and then stored in $70 \%$ ethanol. Some slugs collected as juveniles were raised to adulthood in a constant temperature chamber at $15^{\circ} \mathrm{C}$. Body lengths depend on whether measured on living slugs fully stretched when crawling, or on slugs killed in ethanol, or killed by ultrafreezing. We indicate these different types of measurement by the suffix L, E or F respectively. An experiment with $D$. reticulatum indicated a relation between the different measurements of roughly $\mathrm{E}=0.6 \mathrm{~L}$ and $\mathrm{F}=0.5$ to $0.7 \mathrm{~L}$. All specimens are in the collection of the State Museum of Natural History Görlitz.

We dissected the animals in a standard way, by cutting the skin just along the left foot fringe and then peeling the dorsal skin over to the right side. All drawings were made initially using a camera lucida.

\section{RESULTS}

\section{LOCALITIES AND EXTERNAL CHARACTERISTICS}

Figure 2 shows the collecting sites listed in the following sections.

\section{Czech Republic}

1) Sudeten Mountains, western Hrubý Jeseník, 16 km SW of Jeseník, ca. $17^{\circ} 01^{\prime} \mathrm{E}, 50^{\circ} 08^{\prime} \mathrm{N}$. Beech forest, road margin 200 to $800 \mathrm{~m} \mathrm{~S}$ of Branná. Altitude ca. $550 \mathrm{~m}$.

Collection: 16th May 1999, 45 fully grown slugs. 20 slugs dissected: 18 were D. turcicum and $2 D$. praecox. The latter tended to be slightly larger, and more intensely dotted, but externally did not differ considerably.

Size: D. turcicum: $23_{\mathrm{L}} \mathrm{mm}\left(22_{\mathrm{F}} \mathrm{mm}\right), 35_{\mathrm{L}} \mathrm{mm} ; 16$ slugs $17-29_{\mathrm{F}} \mathrm{mm}$; D. praecox: $29_{\mathrm{F}} \mathrm{mm}, 30_{\mathrm{F}} \mathrm{mm}$.

Coloration: both species light cream with greyish spotting ranging from very little to more intense. western Carpathian and Sudeten Mountains, embedded within that of $D$. rodnae but overlapping little or not at all.

In all figures the orientation is with the slug's head pointing away from the observer (Fig. 1).

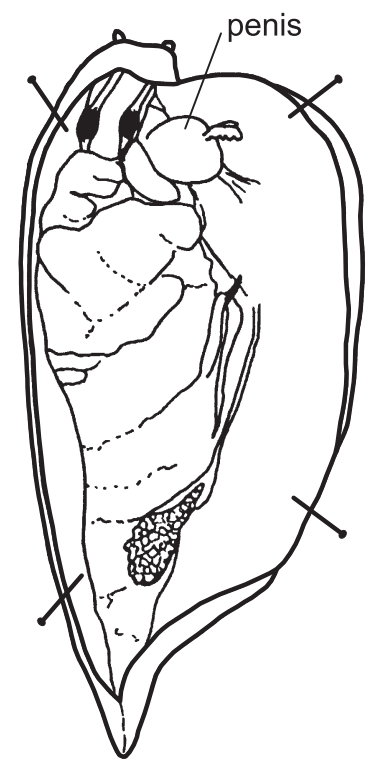

Fig. 1. Dissection method

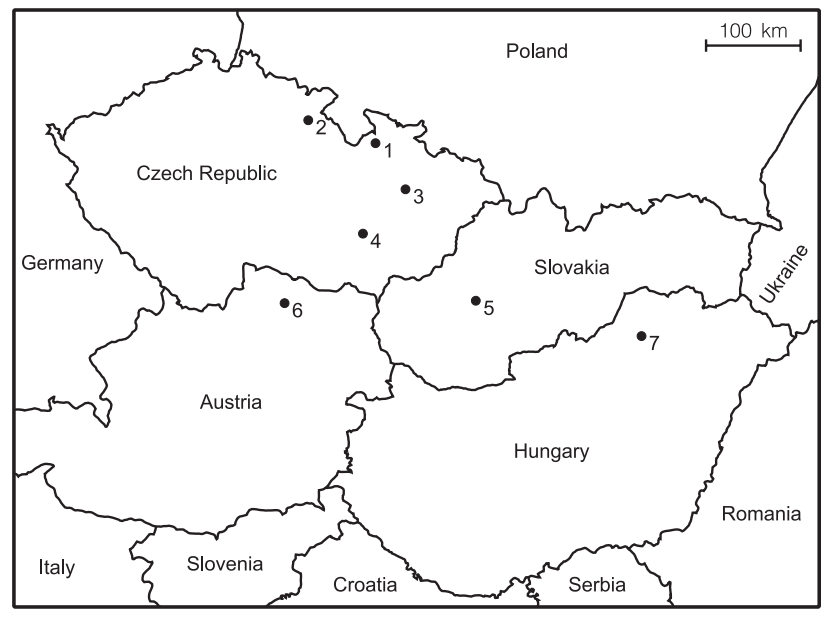

Fig. 2. Collecting sites; for numbers see text

2) Sudeten Mountains, Orlické Hory, Rýzmburk at stream Úpa, $12 \mathrm{~km} \mathrm{NE}$ of Jaroměř, ca. $16^{\circ} 03^{\prime} \mathrm{E}$, $50^{\circ} 26^{\prime} \mathrm{N}$. Forest along stream (mainly beech, hornbeam, oak, a few conifers). Altitude ca. $310 \mathrm{~m}$. 
Collection: 15th May 1999, 19 fully grown slugs and 1 smaller slug. All 15 slugs dissected were adult $D$. turcicum.

Size: 14 slugs $18-24_{\mathrm{F}} \mathrm{mm}, 1$ slug $16_{\mathrm{F}} \mathrm{mm}$.

Coloration: the small slug was light cream with very few, scarcely visible spots; all others were white without spotting (Fig. 3c).

We also examined a sample of 8 specimens collected by BRABENEC at the same locality on 29th April 1968 and labelled as D. praecox (mentioned in HUDEC 1970; specimens are in the National Museum of Natural History Prague, Brabenec collection, number P6p 166/1974). Two of the slugs had been dissected, and were indeed adult $D$. praecox. However, we dissected 4 further slugs, of which 3 were adult D. turcicum and 1 an adult $D$. praecox. Externally, the species were indistinguishable. All slugs were snowy white, and had no spots. The internal organs were unpigmented (even the penes, as in our specimens), and (in contrast with ours) the gonad and digestive gland were only slightly creamish. This gave the impression that the slugs were albinos. The sizes of $D$. praecox were $20-32 \mathrm{~mm}$, and of D. turcicum 27-28 mm (all slugs extended).

3) Sudeten Mountains, Oderské Vrchy, $15 \mathrm{~km}$ NE of Olomouc, Hrubá Voda.

We collected at two sites:

3a) Mountains NW of the village, $17^{\circ} 26^{\prime} \mathrm{E}, 49^{\circ} 52.2^{\prime} \mathrm{N}$. Dense forest (ash, beech, hornbeam) and high undergrowth (mainly Lunaria rediviva) due to earlier logging. Altitude ca. $530 \mathrm{~m}$.

Collection: 17th May 1999, 21 slugs (4 very small but at least one of these was sexually mature; 17 fully grown and appearing senescent). 11th June 1999, only 4 more slugs found (looking unhealthy; 3 sexually mature, 1 juvenile). 22 slugs dissected, all $D$. turcicum.

Size: 1 juvenile $11_{\mathrm{F}} \mathrm{mm}, 17$ adults $17-26_{\mathrm{F}} \mathrm{mm} ; 3$ slugs put into ethanol after they had died (including two violet slugs): $15-25 \mathrm{~mm}$.

Coloration: 3 of the animals from the first date had a striking greyish violet colour (Fig. 3a, b); all others were cream to brownish cream (Fig. 3a). All were rather intensely greyish spotted.

3b) Northern margin of the village, beech wood above stream, ca. $17^{\circ} 26.5^{\prime} \mathrm{E}, 49^{\circ} 51.1^{\prime} \mathrm{N}$. In litter and on ground vegetation. Altitude ca. $400 \mathrm{~m}$.

Collection: 17th May 1999, 15 D. turcicum. 11th June 1999, 2 D. turcicum and 1 D. praecox.

Size: D. turcicum: 2 juveniles $14_{\mathrm{F}} \mathrm{mm}, 12_{\mathrm{E}} \mathrm{mm}, 16$ adults (including violet slug) $17-24_{\mathrm{F}} \mathrm{mm}, 3$ adults $18-20_{\mathrm{E}} \mathrm{mm}$; D. praecox: $28_{\mathrm{F}} \mathrm{mm}$.

Coloration: D. turcicum: 1 slug violet, the rest cream, all with intense greyish spotting. D. praecox: cream with intense grey spotting (like most D. turcicum).
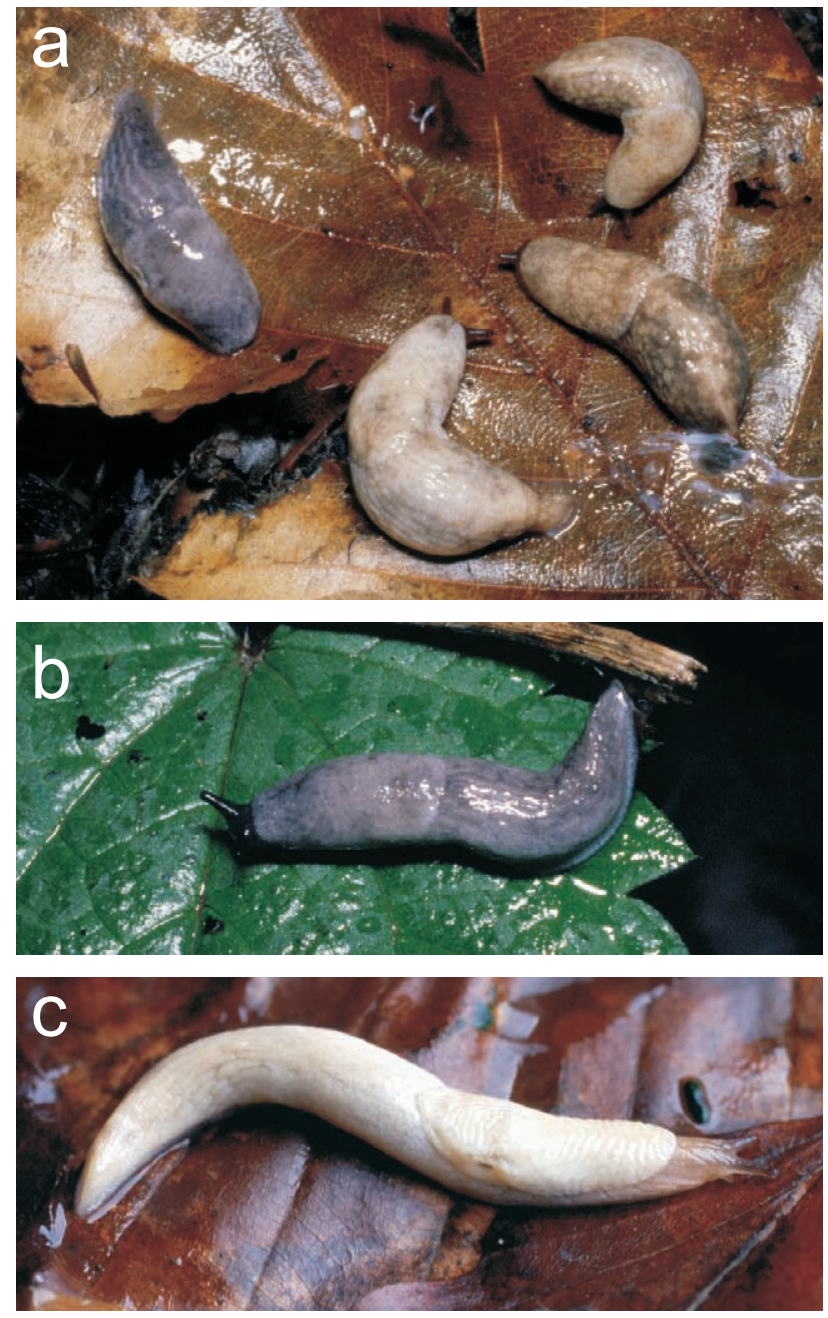

Fig. 3. Colour morphs of D. turcicum (a and b from Locality $3 a, c$ from Locality 2): a -3 cream and 1 violet individuals; $b$ - violet individual (different from that in a); c - white individual

The slugs from Locality 3 seem to be slightly different from the other D. turcicum considered in this paper: they are comparatively small, have a violet colour morph, and are also more difficult to keep and breed in the laboratory. We are currently carrying out breeding experiments to study the genetics of the colour polymorphism.

4) Českomoravská vrchovina, Drahanská vrchovina, ca. $11 \mathrm{~km} \mathrm{NE}$ of Brno, between Hostěnice and Ochoz, above Hádek, $16^{\circ} 45^{\prime} \mathrm{E}, 49^{\circ} 16^{\prime} \mathrm{N}$. Beech wood with single spruce trees along road. Altitude ca. $400 \mathrm{~m}$.

Collection: 21st May 1999, about 40 slugs, most fully grown. 13 specimens dissected: 12 adult $D$. turcicum, 1 juvenile (species identity unknown).

Size: 7 slugs $20-26_{\mathrm{F}} \mathrm{mm}, 4$ slugs $21-23_{\mathrm{E}} \mathrm{mm}$; 2 slugs reared till mid-June: 1 juvenile $15_{\mathrm{F}} \mathrm{mm}, 1$ adult $16_{\mathrm{F}}$ $\mathrm{mm}$.

Coloration: light cream to brownish cream, usually with brownish-grey spotting. 


\section{Slovakia}

5) Tribeč Mountains, S of Partizánske. We collected at several localities in the area between Partizánske, Vel'ký Klíž and Kolačno, 18 20'-18 24'E, $48^{\circ} 34.5^{\prime}-48^{\circ} 37^{\prime} N$. Mostly rather dry wood with oak, hornbeam and the grass Melica, and locally beech. Altitudes ca. 200-500 m.

Collection: 7th May 1993, 7 adult and 1 juvenile $D$. turcicum. 20th May 1999, 1 D. praecox (at a disturbed site with garden waste).

Size: D. turcicum: 1 juvenile $15_{\mathrm{F}} \mathrm{mm}$ (species identity uncertain); 7 adults $16-23_{\mathrm{E}} \mathrm{mm}$ (2 of these $37_{\mathrm{L}}$ $\left.\mathrm{mm}, 47_{\mathrm{L}} \mathrm{mm}\right)$. D. praecox: 1 adult $27_{\mathrm{E}} \mathrm{mm}$.

Coloration: D. turcicum: brownish cream, intensely spotted; $D$. praecox: brownish cream, very intensely greyish spotted (more than in the D. turcicum, similar to typical $D$. reticulatum).

We also collected at another locality, about $11 \mathrm{~km}$ north-east of Partizánske, $18^{\circ} 29.5^{\prime} \mathrm{E}, 48^{\circ} 40.5^{\prime} \mathrm{N}$. On the two occasions only $D$. praecox was found.

Collection: 8th May 1993, 1 adult. 20th May 1999, 4 adults, 1 very small juvenile (probably just hatched).

Size: 5 adults $27_{\mathrm{F}}, 29_{\mathrm{F}}, 20_{\mathrm{F}}=30_{\mathrm{L}}$, ca. $11_{\mathrm{E}}=26_{\mathrm{L}}$, $19_{\mathrm{E}}=40_{\mathrm{L}} \mathrm{mm} ; 1$ juvenile $3_{\mathrm{L}} \mathrm{mm}$ (later raised until August).

Coloration: cream, sparsely to very intensely greyish spotted.

\section{Austria}

6) Lower Austria (Niederösterreich), Waldviertel, Steinegg, $48^{\circ} 37.5^{\prime} \mathrm{N}, 15^{\circ} 34^{\prime} \mathrm{E}$. Beech forest near river Kamp. Altitude ca. $400 \mathrm{~m}$.

Collection: 20th August 1997, several young slugs collected, but only two survived until adulthood: $1 D$. turcicum and 1 D. rodnae.

Size: D. turcicum: $18_{\mathrm{E}} \mathrm{mm}$ (killed November 1999, adult); D. rodnae: ca. $25_{\mathrm{F}} \mathrm{mm}$ (killed December 1999, adult).

Coloration: both species cream, strongly greyish spotted.

\section{Hungary}

7) Bükk Mountains.

7a) Bükki Nemzeti Park, near Lillafüred (W of Miscolc). Beech forest beside road along Lake Hámori, 4807’ N, 20³5'E. Altitude ca. 350 m.

Collection: 23rd January 1998, 4 D. turcicum (probably all adult or subadult).

Size: 1 adult $21_{\mathrm{E}} \mathrm{mm}$, others killed 16th April 1999 $\left(27_{\mathrm{E}}, 21_{\mathrm{F}}, 25_{\mathrm{F}} \mathrm{mm}\right.$, adults $)$.

Coloration: cream to brownish cream, strongly greyish spotted.

7b) ca. $1.2 \mathrm{~km}$ east of Varbó (church), underneath hill Csörgo teto, $48^{\circ} 08^{\prime} \mathrm{N}, 20^{\circ} 38^{\prime} \mathrm{E}$. Beech forest beside road between Miskolc and Varbó. Altitude $250 \mathrm{~m}$.

Collection: 23rd January 1998, 1 D. turcicum, kept alive till 16th April 1998.

Coloration: brownish cream, strongly spotted.

\section{SIGNIFICANCE OF EXTERNAL CHARACTERS}

Evidently $D$. turcicum is very variable in its external features (Fig. 3). Like D. praecox and D. rodnae, its coloration can be completely white and unspotted, as well as light or brownish cream with different amounts of dark spotting. It can even be violet like some D. rodnae (REISE 1997, WIKTOR 2000). This means that $D$. rodnae is not unique in having a violet colour morph (WÜTHRICH 1994, JORDAENS et al. 1998, REISE et al., in prep.). Neither the violet nor the white unspotted morphs have been reported previously in D. turcicum.

It is interesting that at sites where D. turcicum cooccurred with $D$. rodnae or D. praecox, the two species always had similar coloration and spotting. If we rule out introgression, this suggests a selective value of the coloration. Just after dawn and in wet weather active slugs can be found in some abundance, and the pale morphs in particular stand out strongly against a dark unvegetated woodland floor. So one intriguing possibility is that the resemblance is due to mimicry of warning coloration.

D. turcicum has been considered as a comparatively small species of ca. 20-25 mm (in ethanol; REISCHÜTZ 1986, WIKTOR 2000). However, we found a considerable overlap with the other three species, not only because these species can be as small, but also because some $D$. turcicum can reach a larger size.

\section{COMPARISON OF ANATOMICAL CHARACTERS}

Most D. turcicum (Fig. 4a-c) have a bipartite penis with a bulbous distal part and a narrower proximal part. The distal end of the proximal part has a slight depression in the middle where the vas deferens enters the penis. The vas deferens runs along the penis surface and is visible when dissected in the way shown in Fig. 1. The retractor inserts at the back side some distance away from the insertion of the vas deferens. Attached to a bulge above the insertion of the vas deferens are the penial glands. These usually branch from a common trunk and are short or medium long. The wall of the distal part of the penis facing the body wall is thick and soft. Inside this is the stimulator, which typically is rather short and fleshy but more or less flattened, has a wide base, and is prolonged to a tip on the left side as viewed in the figure (Fig. 5a-f, i, j).

However, D. turcicum is extremely variable with respect to its distinguishing anatomical characters. Table 1 summarises the variation within and between localities. The penis can be a single sac-like bag 

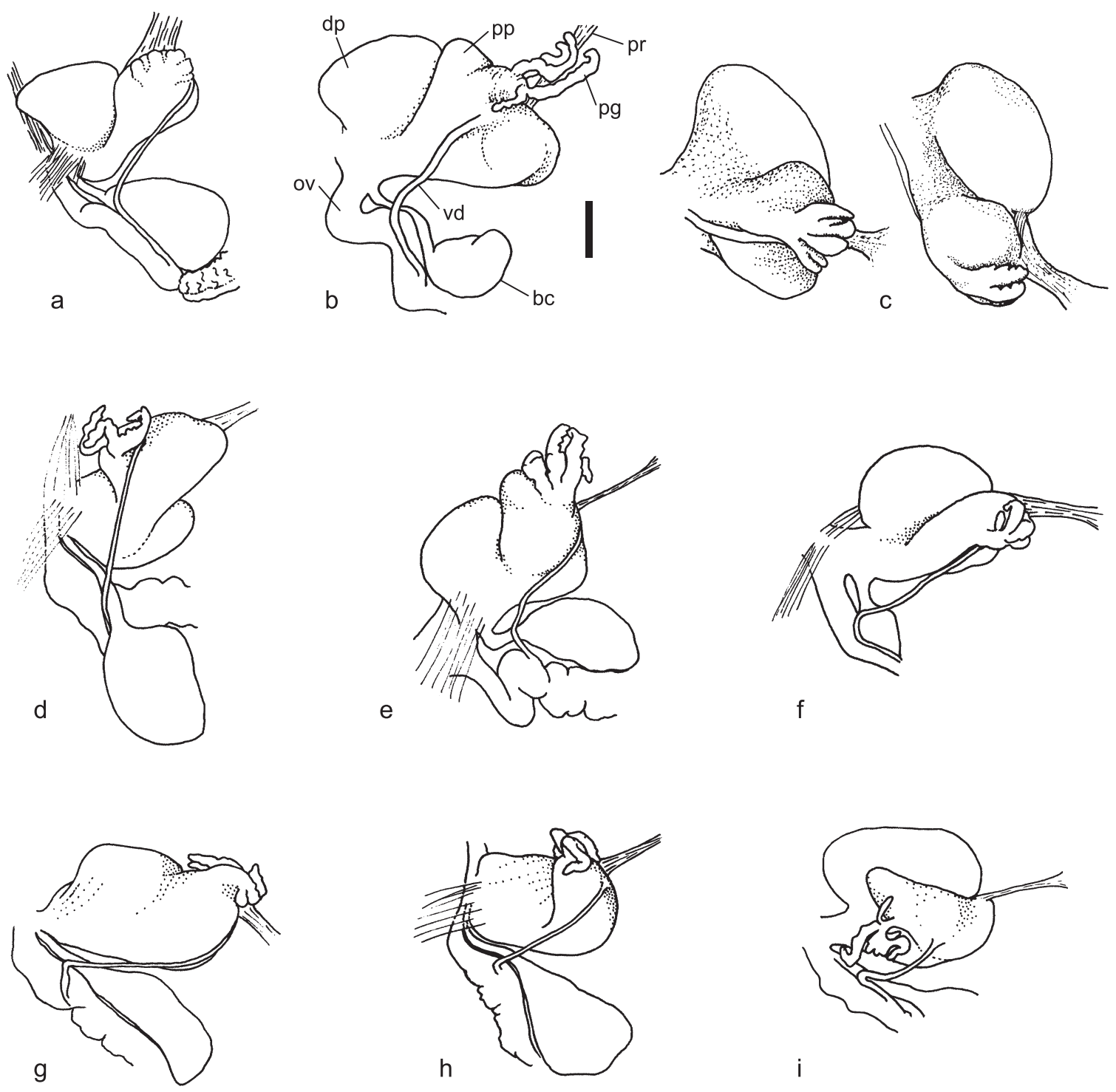

i
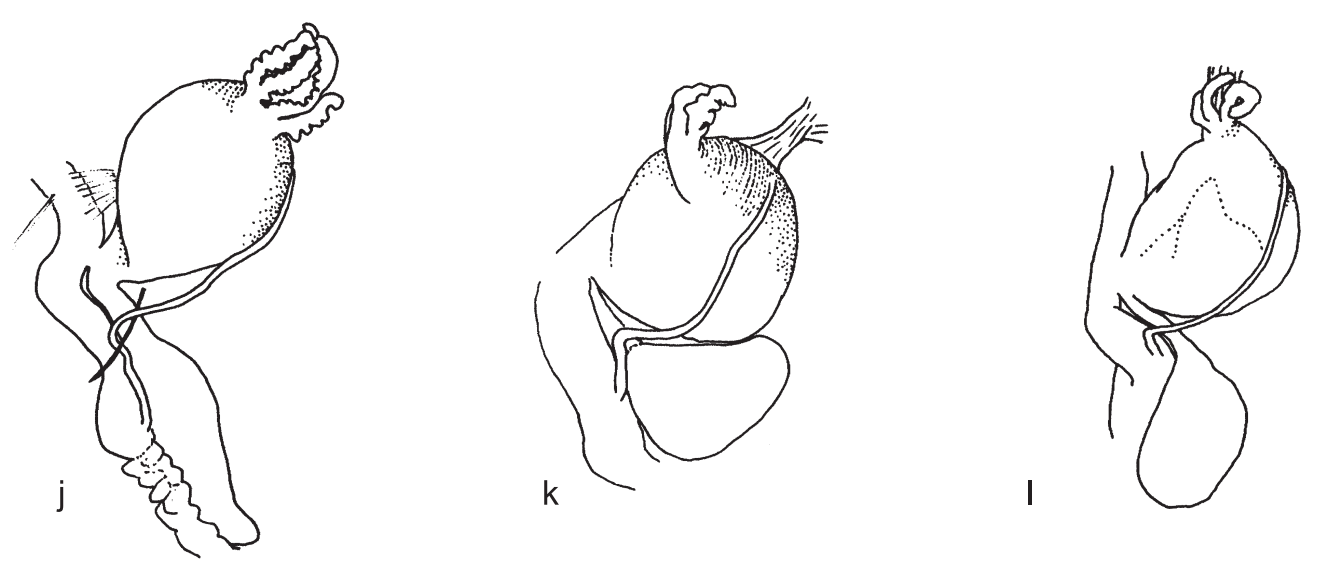

Fig. 4. D. turcicum, diversity of distal genitalia. Origins of slugs: c, i - Locality 2; e - Locality 3a; b, j- Locality 4; d, g, h, l- Locality 5; f - Locality 6; k - Locality 7; a - Macedonia, near Lake Ohrid, locus typicus; Collectors: c - Brabenec, 1968; a - Wiktor, 1983; all others - authors, 1993-1999 (see text). bc - bursa copulatrix, dp - distal part of penis, ov - oviduct, pg - penial glands, pp - proximal part of penis, pr - penis retractor, vd - vas deferens. The dotted line in 1 indicates the position of the stimulator. Scale bar $=1 \mathrm{~mm}$ 


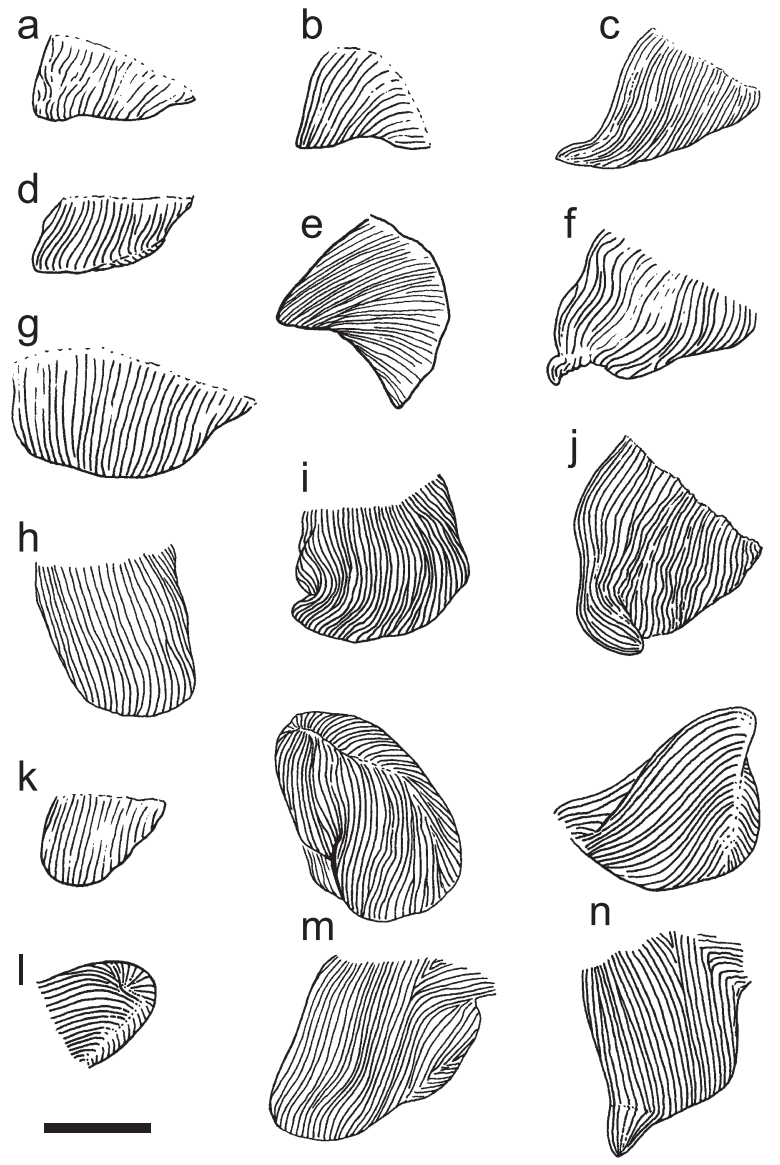

Fig. 5. D. turcicum, diversity of stimulators: a-k - penes bipartite, l-n - penes sac-like. Origins of slugs: b - Locality 1 ; e Locality 2; a, k - Locality 3a; d, f, g, m - Locality 4; h, i, l, n - Locality 5; c, j - Locality 7. Scale bar $=1 \mathrm{~mm}$

(Fig. 4j-1), or, rarely, seemingly intermediate between this and the usual bipartite form (Fig. 4g, h). Undivided penes may be typical for juvenile individuals (WIKTOR, pers. comm.). However, slugs listed as having sac-like penes in Table 1 were fully grown and sex-
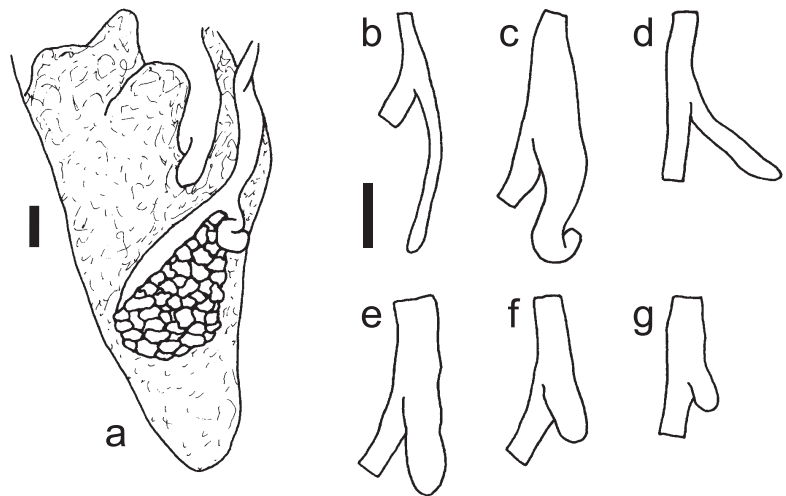

Fig. 6. D. turcicum, diversity of rectal caecum lengths. Origins of slugs: a - Locality 2; f, b - Locality 4; c, e, g-Locality 5 ; $\mathrm{d}-$ Locality 6 . Scale bars $=1 \mathrm{~mm}$

ually mature. The penial glands (usually 3 or 4 ) also show a wide range of forms, from rather short unbranched fingers giving a hand-like appearance, to very long, thin, branched or unbranched fingers (Fig. 4). Probably the most variable structure is the stimulator (Fig. 5). It can be short or long, flattened or fleshy and nearly conical, and its end is not always pointed but can be more or less rounded.

The rectal caecum of D. turcicum is always unambiguously present and in almost all cases much longer than wide (Fig. 6). However, its length varies considerably, and we found no correlation with the site of collection. The caecum of one specimen from Locality 5 is only a little pocket about as long as wide (Fig. 6g); we nevertheless determined it as D. turcicum because its penis is typical of this species.

Fig. 7 shows the anatomical characters of $D$. reticulatum, $D$. rodnae and $D$. praecox. It is evident that at least the first two species are extremely similar to some $D$. turcicum. D. praecox can usually be recognised by its coiled penial appendix, although one specimen of $D$. turcicum has a small appendix-like bag on the proximal

Table 1. Distribution of penis morphotypes at the localities 1 to $7.2^{*}=$ collected by BRABENEC $1968,+=$ present,$-=$ absent, $\pm=$ present but not of the typical form, ( ) = present, but in minority.

\begin{tabular}{|c|c|c|c|c|c|c|c|c|}
\hline LOCALITY & 1 & 2 & $2^{*}$ & 3 & 4 & 5 & 6 & 7 \\
\hline \multicolumn{9}{|l|}{ PENIS SHAPE } \\
\hline bipartite & + & + & + & + & & $( \pm+)$ & + & + \\
\hline sac-like & & & & $(+)$ & $(+)$ & + & & + \\
\hline \multicolumn{9}{|l|}{ VAS DEFERENS } \\
\hline on upper penis surface & + & + & + & + & + & $+( \pm)$ & + & + \\
\hline \multicolumn{9}{|l|}{ PENIAL GLANDS } \\
\hline short or medium & + & $( \pm)$ & + & + & $(+)$ & + & + & + \\
\hline long & + & + & & + & + & & & + \\
\hline \multicolumn{9}{|l|}{ STIMULATOR } \\
\hline short (s) or long (l) & s & $\mathrm{s}$ & $\mathrm{s}$ & s (1) & $\mathrm{s}(\mathrm{l})$ & 1 & $\mathrm{~s}$ & 1 \\
\hline flattened & + & $+( \pm)$ & + & $+( \pm)$ & $+( \pm-)$ & $\pm(+)$ & + & + \pm \\
\hline pointed end at one side & + & \pm & + & \pm & $+(-)$ & $+(-)$ & + & + \\
\hline
\end{tabular}



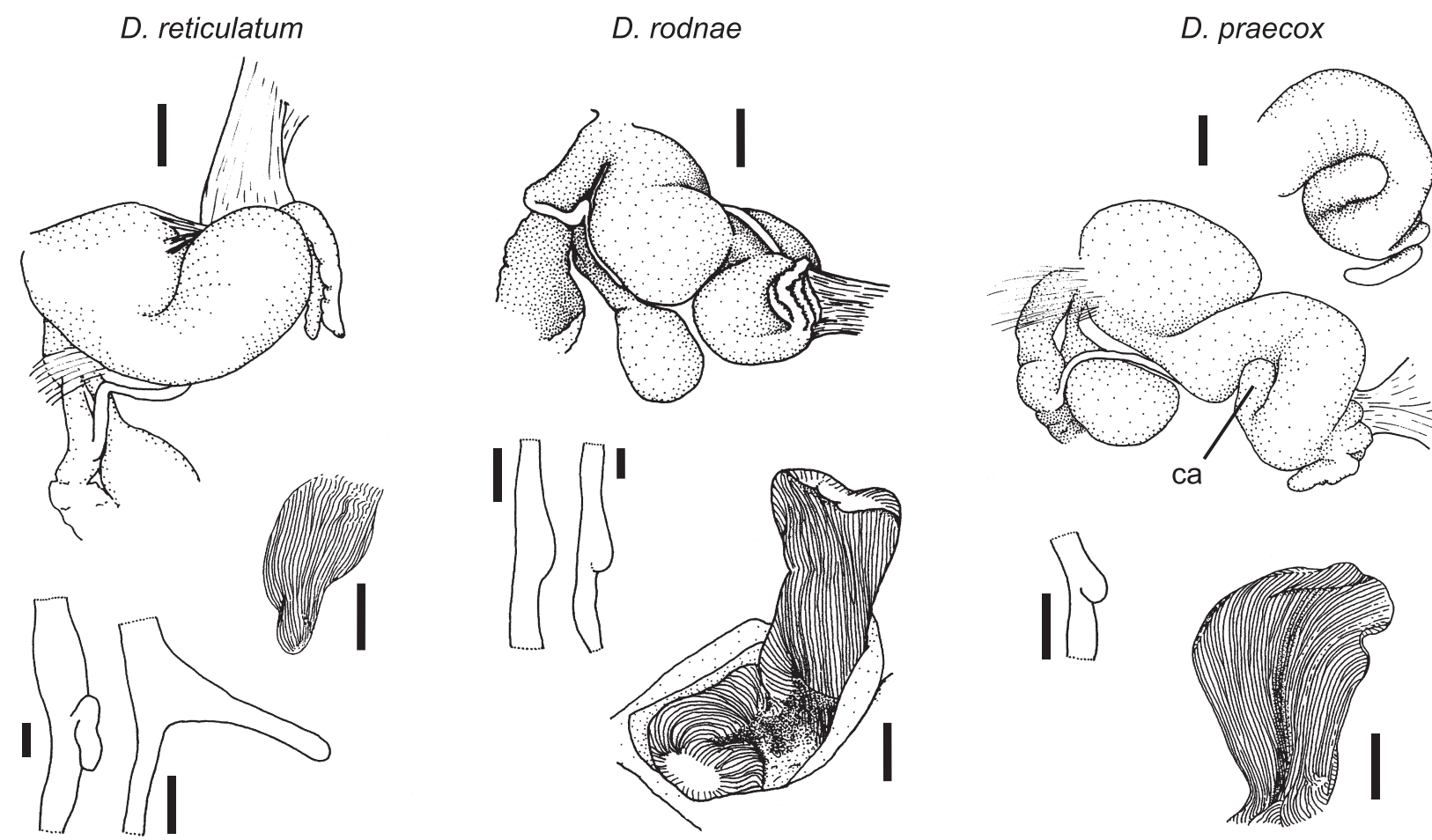

Fig. 7. Distal genitalia, stimulators and caeca of three species similar to D. turcicum. D. reticulatum: Görlitz (Germany, Saxony), 20th September 2000. D. rodnae: penis and left caecum from Knechtsbachtal (Germany, Saxony, mountain range Sächsische Schweiz), 18th June 1996; stimulator and right caecum from Kří ový Buk (Czech Republic, Lu ické Hory), 17th May 1994. D. praecox: penis from Rýzmburk (Czech Republic, near Jaroměř), 29th April 1968 collected by BRABENEC; stimulator and caecum from Babia Góra (Poland), 18th May 1999. Two views of the coiled appendix (ca) of the same specimen of $D$. praecox are shown. Scale bars $=1 \mathrm{~mm}$

end of its penis (Fig. 4i). Both D. praecox and D. rodnae can usually be distinguished from almost all $D$. turcicum by their strongly reduced rectal caecum. The long flattened and rounded stimulator of $D$. rodnae probably cannot be used to separate it reliably from $D$. turcicum. Most of our D. turcicum have a more or less flattened stimulator, which occasionally is rather long or has a rounded end. The stimulator of one D. turcicum was both long and rounded (Fig. $4 \mathrm{~g}$ ); such cases will appear extremely similar to $D$. rodnae. D. reticulatum is even more difficult to distinguish from D. turcicum since both have an obvious rectal caecum and some $D$. turcicum have a stimulator which is long and fleshy and rather conical, as in D. reticulatum.

The most reliable character to distinguish $D$. turcicum from the other three species seems to be the position of the vas deference which WIKTOR (2000) described as at the "side of penis facing viscera and thus on the body axis". This corresponds to the side of the penis visible to the viewer when the slug is dissected as described above. The site where the vas deferens joins the penis is close to the base of the penial glands but rather distant from the insertion of the penis retractor. However, in a few cases the vas deferens is situated more laterally (e.g. Fig. 4g). This character should be used together with the other ones: we never found all "untypical" patterns (penis shape, position of vas deferens, stimulator, caecum) together.

A. WIKTOR (pers. comm.) has suggested the position of the ovotestis as a further character that might distinguish $D$. reticulatum from $D$. turcicum. LUTHER (1915) proposed this as a character to separate $D$. reticulatum from Deroceras agreste (L., 1758). In the 26 specimens from 8 localities that we have checked, the ovotestis of D. turcicum is smaller and more hidden than in $D$. reticulatum. It extends caudally most often to about a half to two-thirds of the distance from the base of the rectal caecum to the tail end of the body cavity, while it extends to the end or nearly the end in D. reticulatum. This distinction needs to be checked in further populations of both $D$. reticulatum and $D$. turcicum. It would also be necessary to examine how the character depends on maturity.

\section{DISCUSSION}

Our new findings prove that the range of $D$. turcicum reaches much further north than previously

recognised. The species had not been recorded from the Czech Republic or Slovakia. The number of local- 
ities and its abundance at some of these sites suggest that D. turcicum might even be rather common. It now seems not unlikely that the species occurs also in Poland and Germany. Malacologists there should be aware of this when collecting Deroceras in deciduous or mixed woods.

The abundance of the species at two localities in the Czech Republic (localities 1 and 4) makes one wonder why $D$. turcicum has not been detected there much earlier. The same question applies to localities that have been investigated by malacologists before: Oderské Vrchy (HuDEC 1967), Tribeč Mountains (KROUPOVÁ 1982), Kamptal near Steinegg, Waldviertel (REISCHÜTZ 1984). D. turcicum has been recorded before from the Bükk Mountains (WIKTOR \& SZIGETHY 1983, BÁBA 1992) but only at two localities despite this being an area of quite intensive surveying for molluscs (e.g. BÁBA et al. 1983). We cannot exclude the possibility that $D$. turcicum has been expanding from the Balkans towards Central Europe. However, BRABENEC collected his sample from Rýzmburk in 1968, and confusion of D. turcicum with other species seems a more likely explanation.

WIKTOR $(1983,1996,2000)$ has repeatedly stressed the similarity of $D$. turcicum to $D$. reticulatum and the high chance of misidentification. However, D. turcicum might more often have been confused with $D$. rodnae, owing not only to their similar penis shapes, but also to their similar habitats. The sample from Rýzmburk shows that D. turcicum can also be confused with $D$. praecox, again because of the similar external appearance and habitat. Although D. turcicum can occasionally be found in synanthropic habitats (WIKTOR 2000 ), it is mainly restricted to woodland. It seems to be rather flexible with respect to the kind of wood: we have found it not only in rather dry oak and hornbeam forests, but more often and in greater abundance in old damp beech forests. For this reason, we suggest that Central European D. turcicum probably more often co-occurs with $D$. rodnae or $D$. praecox than with $D$. reticulatum.

It is indeed striking how similar the three species are to $D$. turcicum. At none of our collecting sites had we any external indication that we had collected two different species of Deroceras. Therefore, samples of D. rodnae, $D$. praecox, or even $D$. reticulatum from suitable habitats should be carefully reanalysed. It is necessary to dissect a number of specimens, both because it may be only a proportion of a collection that is D. turcicum, and because $D$. turcicum's high variability can make species determination difficult if based on single specimens.

It cannot be ruled out that some published localities of D. rodnae in Slovakia and Czech Republic are due to misidentifications of D. turcicum. This is especially interesting for sites in Slovakia where sympatric occurrences of the usually allopatric $D$. praecox and $D$. rodnae have been reported (LISICKÝ 1991). For instance, sympatry has been claimed in the Tribeč Mountains around Partizánske (KROUPOVÁ 1982, pers. comm.). We have collected there twice, and found only $D$. turcicum and $D$. praecox. This mountain range is dominated by dry warm forests with oak, hornbeam and pine, which seems to fit the habitats of $D$. turcicum much better than those of $D$. rodnae (WIKTOR 1983, REISCHÜTZ 1986). Unfortunately, many samples in the Zoological Institute of Bratislava collected by KROUPOVÁ (later LUČIVJANSKÁ) have dried out after her death, including all more or less adult specimens from this area labelled as D. rodnae. It would thus be most valuable to search anew for $D$. rodnae from this area, as well as to check samples from neighbouring areas.

Given the difficulty of distinguishing D. turcicum, one might wonder whether it represents a real taxonomic unit. However, a preliminary enzyme study including specimens from three of the Czech localities, and the Slovak and the Hungarian localities, has indicated D. turcicum's taxonomical integrity, and a close relationship with $D$. reticulatum (REISE et al., in prep.).

\section{ACKNOWLEDGEMENTS}

We are grateful to V. PfLeger (National Museum of Natural History Prague) for the loan of slugs, to J. ŠTEFFEK for all his efforts to make the collection of $\mathrm{V}$. Lučivjanská available to us, and to L. PINTÉR for information on a Hungarian locality. S. ZIEBART, K. BULMAN and T. SZÉKELY helped us to collect some of the slugs. Thanks to T. BACKELJAU, B. BAUR, I. FLASAR, and A. WIKTOR for their comments on the manuscript. A. WIKTOR (Museum of Natural History Wrocław) deserves our particular thanks also for his insightful discussion of our ideas, for checking some of our identifications, and for providing a specimen of D. turcicum from the type locality.

\section{NOTE ADDED IN PROOF}

A paper by S. V. Jovanović (1999, Arch. Biol. Sci., Belgrade 51 (4): 219-233), on D. turcicum from Macedonia, was discovered too late to be discussed here. However, the distinguishing characters proposed there seem not to apply consistently to our specimens. 


\section{REFERENCES}

BÁBA K. 1992. Terrestrial snail assemblages in the Bükk Mountains. Abstr. bot. 16: 109-127.

BÁBA K., VARGA A., WAGNer M., Zseni L. 1983. Daten zu den die Verbreitung der Landschnecken im Bükk-Gebirge beeinflussenden biotischen Faktoren. Soosiana 10/11: 25-30.

BARKER G. M. 1999. Naturalised terrestrial Stylommatophora (Mollusca: Gastropoda). Fauna of New Zealand 38. Manaaki Whenua Press, Lincoln, Canterbury, N.Z.

DHORA D., WELTER-SCHUlTES F. W. 1996. List of species and atlas of the non-marine molluscs of Albania. Schr. Malakozool. 9: 90-197.

HUDEC V. 1967. Neue Funde der Nacktschnecken Lytopelte herculana Grossu, 1964 in Bulgarien und Deroceras praecox Wiktor, 1966 in der Tschechoslowakei (Mollusca). Věstník Čs. spol. zool. 31: 349-354.

HudEC V. 1970. Für die Tschechoslowakei neue Nacktschneckenarten (Pulmonata, Limacidae, Deroceras). Biológia, Bratisl. 25: 109-122.

JORDAENS K., BACKELJAU T., REISE H., VAN RIEL P., VERHAGEN R. 1998. First record of Deroceras juranum outside the Jura Mountains (Pulmonata: Agriolimacidae). J. Moll. Stud. 64: 495-499.

KROUPOVÁ V. 1982. Mäkky̌še a možnosti využitia ich výskumov pri ochrane prírody horného Ponitria. Homa Nitra 10: $129-153$.

LISICKÝ M. J. 1991. Mollusca Slovenska. Slovak Academy of Sciences, Bratislava.

LUPU D. 1972. Étude anatomique comparé de quelques espèces du genre Deroceras Rafinesque 1820. Trav. Mus. Hist. nat. "Grigore Antipa" 12: 85-100.

LUTHER A. 1915. Zuchtversuche an Ackerschnecken (Agriolimax reticulatus Müll. und Agr. agrestis L.). Acta Soc. Fauna Flora fenn. 40: 1-42.
REISCHÜTZ P. L. 1984. Beiträge zur Molluskenfauna Niederösterreichs, VI. Die Molluskenfauna des Kamptales zwischen Schloß Rosenburg und der Ruine Steinegg (Waldviertel). Heldia 1: 29-32.

REISCHÜTZ P. L. 1986. Die Verbreitung der Nacktschnecken Österreichs (Arionidae, Milacidae, Limacidae, Agriolimacidae, Boettgerillidae). Sitzungsber., Österr. Akad. Wiss., Math.-Naturwiss. Kl., Abt. I 195 Suppl. 2: 67-190.

REISE H. 1997. Deroceras juranum - a Mendelian colour morph of D. rodnae (Gastropoda: Agriolimacidae). J. Zool. Lond. 241: 103-115.

REISE H., BACKELJAU T., ZIMDARS B., in prep. Systematics and population genetic structure in a complex of cryptic terrestrial slugs - an allozyme study (Mollusca: Pulmonata: Agriolimacidae).

WIKTOR A. 1983. The slugs of Bulgaria (Arionidae, Milacidae, Limacidae, Agriolimacidae - Gastropoda, Stylommatophora). Ann. Zool. 37: 71-206.

WIKTOR A. 1996. The slugs of the former Yugoslavia (Gastropoda terrestria nuda - Arionidae, Milacidae, Limacidae, Agriolimacidae). Ann. Zool. 46: 1-110.

WikTOR A. 2000. Agriolimacidae (Gastropoda: Pulmonata)a systematic monograph. Ann. Zool. 49: 347-590.

WikTOR A., SzIGETHY A. S. 1983. The distribution of slugs in Hungary (Gastropoda: Pulmonata). Soosiana 10/11: 87-111.

WÜTHRICH M. 1994. Deroceras (Plathystimulus) juranum n. sp., eine endemische Nacktschnecke aus dem Schweizer Jura. Arch. Moll. 122: 123-131.

received: March 15th, 2001

accepted: May 20th, 2001 